\title{
Analysis of Nitrogen Utilization and Excretion in Growing Dairy Cattle ${ }^{1}$
}

\author{
G. I. Zanton and A. J. Heinrichs ${ }^{2}$ \\ Department of Dairy and Animal Science, The Pennsylvania State University, University Park 16802
}

\begin{abstract}
Literature data on utilization of dietary $\mathrm{N}$ were analyzed by using meta-analytic procedures for growing milk-fed dairy calves and weaned dairy heifers. The objective was to statistically assess $\mathrm{N}$ utilization and excretion in growing dairy cattle when dietary $\mathrm{N}$ was altered in otherwise balanced rations at various stages of growth. Studies meeting the selection criteria included data from 16 published papers encompassing 94 distinct observations made on 217 animals. Of these, 6 studied calves were fed milk or milk protein-based milk replacer [milk-fed; 30 to $81 \mathrm{~kg}$ of body weight (BW)] with 37 different dietary treatments, and 10 experiments studied heifers receiving diets based on forage, concentrates, or a combination of forage and concentrates (weaned; 56 to $472 \mathrm{~kg}$ of BW) with 57 different dietary treatments. Mixed model and fixed effect regression analyses were used to evaluate responses to additional dietary N. True digestibility of dietary $\mathrm{N}$ was $100.4 \%$ for milk-fed calves and $96.4 \%$ for weaned heifers, with corresponding basal fecal $\mathrm{N}$ excretion values of 3.05 and $6.51 \mathrm{~g}$ of $\mathrm{N} / \mathrm{kg}$ of dry matter intake. Urinary $\mathrm{N}$ ( $\mathrm{g}$ of $\mathrm{N} / \mathrm{kg}$ of $\mathrm{BW}^{0.75}$ ) was consistently greater for milk-fed calves, but the response to increasing $\mathrm{N}$ intake was parallel to the response for weaned heifers. Whether using a mixed model approach or a fixed effect approach to account for metabolizable energy intake, BW, and dry matter intake, milk-fed calves retained more $\mathrm{N}$ per kilogram of $\mathrm{BW}^{0.75}$ than weaned heifers. However, marginal efficiency of $\mathrm{N}$ utilization responded as a continuous function of BW, as opposed to a bimodal response associated with diet type. Gross N efficiency (GNE) responded quadratically to $\mathrm{N}$ intake and was greater for milk-fed calves than for weaned heifers. Linear and quadratic coefficients of this function did not differ between diet types, indicating that the response in gross $\mathrm{N}$ efficiency to additional $\mathrm{N}$ intake was not different
\end{abstract}

\footnotetext{
Received August 17, 2007.

Accepted December 14, 2007.

${ }^{1}$ This research is a component of NC-1042: Management Systems to Improve the Economic and Environmental Sustainability of Dairy Enterprises.

${ }^{2}$ Corresponding author: ajh@psu.edu
}

between diet groups; rather, the absolute level obtainable differed. Dietary CP concentrations of $18.9 \%$ for milk-fed calves and $14.2 \%$ for weaned heifers were found to maximize GNE; 22.5\% MJ of crude protein/ MJ of ME was found to maximize GNE for both groups. Equations are discussed relative to the requirements to replace basal $\mathrm{N}$ losses and efficiency of $\mathrm{N}$ utilization. Key words: nitrogen utilization, dairy calf, dairy heifer

\section{INTRODUCTION}

The importance of protein nutrition in dairy cattle has made it the subject of significant research effort (NRC, 2001). The overwhelming majority of this effort has been directed toward lactating dairy cows because of their central importance to the economic stability of the dairy operation. Protein nutrition of the growing dairy heifer, especially postweaning, has been subject to relatively less investigation. Although protein nutrition of the dairy heifer has been reviewed several times in the past (Blaxter and Mitchell, 1948; Lofgreen et al., 1951; Roy, 1980), the subject has received continued study. Considering the economic burden associated with feeding dairy heifers (Gabler et al., 2000) and the environmental costs associated with overfeeding protein (Kohn et al., 1997), the protein and $\mathrm{N}$ nutrition of dairy heifers assumes added importance for wholefarm sustainability.

Two factors that must be considered when addressing protein requirements of growing animals are that growth occurs on a continuum and that individual tissues can grow at a different rate than the body as a whole. Thus, the growth rate of the whole body and the size, growth rate, and nutrient requirements of an individual tissue may differentially affect nutrient requirements at different stages of growth. These relationships pose a difficulty when attempting to meet nutritional requirements during growth, because an experiment conducted at one phase on the growth curve has absolute validity only at that point. General relationships may emerge, however, from conducting or analyzing numerous experiments at several points along the growth curve. An added difficulty posed by the growing ruminant is the discontinuous mode of digestion and source of nutrients derived from advancing devel- 
opment of the rumen. Proteins from milk are generally of high biological value (Roy, 1970) and can contribute to very high levels of growth. Microbial protein is also a high-quality protein source (Storm et al., 1983) and can meet a significant quantity of the AA requirements in the functional ruminant.

Given the nutritional importance of protein in the growing dairy heifer and the limited information related to $\mathrm{N}$ partitioning, this investigation statistically examined responses to varying amounts of dietary $\mathrm{N}$. Changes that may be related to $\mathrm{BW}$ and $\mathrm{ME}$ also were assessed. Outcome variables of interest in these analyses were measures of $\mathrm{N}$ partitioning as assessed in nutrient digestibility or balance trials, specifically, apparently digestible $\mathbf{N}(\mathbf{A D N})$, fecal $\mathbf{N}(\mathbf{F N})$, urinary $\mathrm{N}(\mathbf{U N})$, $\mathrm{N}$ retained (NR), and $\mathrm{N}$ efficiency. The objective was to statistically evaluate $\mathrm{N}$ retention and excretion in growing dairy cattle in response to increasing levels of dietary $\mathrm{N}$ intake (NI) in otherwise balanced rations fed across various growth stages. A secondary objective was to evaluate $\mathrm{N}$ utilization for basal purposes by extrapolations to zero NI and to compare these estimates between cattle fed liquid, milk protein-based diets and cattle that have been weaned.

\section{MATERIALS AND METHODS}

To accomplish these objectives, a literature search was conducted to identify published reports eligible for analysis. The search was conducted by using two databases for all years available: PubMed (1950 to 2007) and ISI Web of Knowledge/Web of Science (Thomson Scientific; 1900 to 2007). References within published manuscripts identified from the database search were also searched in an attempt to find as many candidate papers for analysis as possible. Books relating to this subject (Roy, 1980; Davis and Drackley, 1998; NRC, 2001) and the references therein were also evaluated. Manuscripts citing the papers found in the database search and reference list search were then evaluated by using the Web of Science. Thus, potential papers were identified from an individual manuscript's own references and papers that referred to it. This process was continued until no further new papers were identified as eligible.

To enter the analysis, the experimental objective must have been to study the effects of differing levels of dietary NI in an otherwise balanced ration. At a minimum, trials had to report NI, FN, BW, and DMI to be included; data were not excluded for not reporting UN or NR. It was also considered acceptable if these responses could be calculated reasonably from other information given in the paper. Data must have been derived from total collection of feces and urine, with adequate procedures in place to minimize $\mathrm{N}$ loss by volatilization. Adequacy of collection procedures was evaluated statistically for FN and UN excretion by a regression of the mean within-trial response against the mean within-trial NI. A trial was removed as an outlying trial if the Studentized residual associated with this analysis was $>3$ standard deviations. Results from slaughter balance-growth trials were not included in the analysis unless results from a total collection trial were also presented.

Given the significance of Holstein-Friesian genetics in the North American dairy industry, the original intention was to analyze the $\mathrm{N}$ balance of only HolsteinFriesian heifers. However, several early studies on the protein nutrition of calves were conducted with other breeds, and implementing this restriction severely limited the number of experiments and animals eligible for analysis. Although there are substantial differences in mature size between large-framed breeds of dairy cattle, before cattle reach $100 \mathrm{~kg}$ there are relatively small differences between breeds in weight and height (Heinrichs and Hargrove, 1994; Heinrichs and Losinger, 1998). Furthermore, Brisson et al. (1957) indicated in an experiment that included Holstein and Ayrshire calves that there were no statistical differences between these 2 breeds in $\mathrm{N}$ utilization. Therefore, large-breed dairy calves were considered eligible for analysis if studied before reaching $100 \mathrm{~kg}$ if all other criteria were met (only experiments with Ayrshire and Holstein-Friesian calves met all criteria and were analyzed). After $100 \mathrm{~kg}$, only dairy cattle of Holstein or Friesian genetics were eligible for analysis. Steers and bulls were considered eligible for analysis provided they were studied before reaching $200 \mathrm{~kg}$ of BW, because at greater BW effects of sex may become more significant in $\mathrm{N}$ retention (Fortin et al., 1980).

Applying these restrictions allowed data from 16 published papers to be used. Of these, 6 studied calves were fed milk or milk protein-based milk replacer (milk-fed group) with 37 different dietary treatments, with animals ranging from 30 to $81 \mathrm{~kg}$ of BW (Blaxter and Wood, 1951b; Brisson et al., 1957; Roy et al., 1970; Raven, 1972; Donnelly and Hutton, 1976; Blome et al., 2003). For animals in the milk-fed group, all nutrition was derived from the milk or milk replacer and no additional feed was offered (either starter grain or hay). Ten published papers studied cattle receiving diets based on forage, concentrates, or a combination of forage and concentrates (weaned group) with 57 different dietary treatments, with animals ranging from 56 to $472 \mathrm{~kg}$ of BW (Whitelaw et al., 1961; Broster et al., 1963; Bowers et al., 1965; Bines and Balch, 1973; Stobo and Roy, 1973; Veira et al., 1980; Bagg et al., 1985; Hoffman et 
al., 2001; Gabler and Heinrichs, 2003; Marini and Van Amburgh, 2003).

Data were analyzed statistically by using mixed modeling methodology to account for variation among trials in mean response as well as differential responses to varying levels of NI (St-Pierre, 2001). In an attempt to isolate effects of different levels of NI apart from other nutritional factors, the following procedures were enacted: if an experiment included multiple levels of DMI, each level was considered a distinct trial. Likewise, several papers reported outcomes of multiple experiments; in these cases, each experiment was considered a distinct trial. This practice allowed subpopulations within a paper to be modeled separately, but reduced the level of independence between trials in that these subpopulations were more closely related than the remaining population that entered the analysis from other papers. Analyses were originally conducted by grouping all outcomes from an individual paper under a single trial effect and by separating outcomes on the basis of other reported information; responses to additional NI were relatively unaffected, but variability of the fitted response was enhanced. From responses observed in this preliminary analysis, it was therefore assumed that loss of independence because of this practice was small relative to the variability that would be introduced by grouping nutritionally distinct groups together under one trial effect.

Several experiments reported data collected longitudinally at 2 or more time points from animals consuming the same diets. Because these results were each derived from the same animals, considering these repeated measures as distinct observations would be a more egregious violation of the assumption of independence. Therefore, results from these experiments were averaged by treatment over time within trial. These practices resulted in what were considered 27 distinct trials with 94 distinct observations made on 217 animals.

Because the objective of the current analysis was to assess the effects of different levels of NI at various stages of growth, it was important that the independent and dependent variables were comparable across large ranges of ages and BW. To enable this comparison, data were scaled to DMI ( $\mathrm{g} / \mathrm{kg}$ of DMI) for analyses of digestion or to $\mathrm{BW}^{0.75}$ for analyses of $\mathrm{UN}$ and NR. This practice allowed considerable overlap and constancy of the independent variables, both within and between milk-fed and weaned cattle over a large range in BW. However, this practice, as well as the lack of reported standard errors in several trials, made weighting data impossible; therefore, data presented in this analysis were not weighted by standard errors. Although scaling data enabled considerable overlap between indepen- dent variables, a substantial portion of variation remained and appeared to be due to differences in weaning status. Therefore, analysis of covariance was used to account for these different subpopulations and to statistically compare responses of milk-fed and weaned cattle to different levels of NI (Gujarati, 1970) by using the indicator variable approach (Suits, 1957). The implication of this analytical approach is that coefficients of the equations are calculated for one nutritional group (weaned cattle, in this case) and the deviations from these coefficients are calculated for the other nutritional group. The statistical test for determining differences between the coefficients of the nutritional groups is then a test of whether each of these deviations is different from zero individually or collectively. All data were analyzed and compared statistically according to the equations presented; however, for ease of exposition and interpretation, individual regression equations for both milk-fed and weaned cattle are presented. This was accomplished by adding the coefficient of the covariate to the main response coefficient.

Linear responses in ADN intake (ADNI) and FN were evaluated according to equation [1] (Table 1), accounting for differences in dietary covariate and random trial effects by using the MIXED procedure of SAS (SAS Institute, 2006). Gross N efficiency for gain (NR/NI; GNE), which responded parabolically, was fit to a quadratic extension of equation [1], as shown in equation [2]. It has been suggested that a physiologically meaningful representation of $\mathrm{ADN} \%$ data may be given by the nonlinear, hyperbolic function: $Y=B_{o}-100 B_{1} / X$, where $Y$ is $\mathrm{ADN}, \% ; B_{o}$ is true $\mathrm{N}$ digestibility, $\% ; B_{1}$ is nondietary FN, g/kg of DMI; and $X$ is NI, g/kg of DMI (Moran and Vercoe, 1972). This expression is essentially the linear model rearranged to relate NI to $\mathrm{ADN} \%$ instead of ADNI. Because ADN\% is of interest in dairy cattle nutrition and is the outcome most readily measurable in digestibility trials, this analysis was included for completeness, although parameter estimates should be similar to those fit by using a linear regression with normally distributed data and a close-to-linear parameterization of the nonlinear model. This equation was extended to account for random trial effects and differences attributable to dietary covariate according to equation [3] (Table 1) by using the NLMIXED procedure of SAS (SAS Institute, 2006).

Previous research indicates that UN responds nonlinearly to increased NI. Roy et al. (1970) modeled nonlinear responses to additional NI by using an exponential function for milk-fed calves. This practice has $2 \mathrm{im}-$ portant advantages over linear or quadratic models: excretion of UN cannot be negative, and coefficient multicollinearity is reduced because polynomial terms 
Table 1. Mixed-effects equations used to describe $\mathrm{N}$ utilization in growing dairy cattle

1. Apparently digestible $\mathrm{N}$ intake, fecal $\mathrm{N}$ ( $\mathrm{g}$ of $\mathrm{N} / \mathrm{kg}$ of $\mathrm{DMI}$ )

$Y_{i j}=\left(B_{o}+B_{o(m)} z_{i}+b_{o i}\right)+\left(B_{1}+B_{1(m)} z_{i}+b_{1 i}\right) X_{i j}+r_{i j}$

$$
\left[\begin{array}{l}
b_{o i} \\
b_{1 i}
\end{array}\right] \sim \mathrm{N}\left[\left(\begin{array}{l}
0 \\
0
\end{array}\right),\left[\begin{array}{cc}
\sigma_{b_{o}}^{2} & \sigma_{b_{o} b_{1}} \\
\sigma_{b_{1} b_{o}} & \sigma_{b_{1}}^{2}
\end{array}\right]\right]
$$

where $B_{o}$ and $B_{1}$ are the intercept and linear coefficients, respectively

2. Gross N efficiency (\%)

$Y_{i j}=\left(B_{o}+B_{o(m)} z_{i}+b_{o i}\right)+\left(B_{1}+B_{1(m)} z_{i}+b_{1 i}\right) X_{i j}+\left(B_{2}+B_{2(m)} z_{i}+b_{2 i}\right) X_{i j}^{2}+r_{i j}$,

$$
\left[\begin{array}{l}
b_{o i} \\
b_{1 i} \\
b_{2 i}
\end{array}\right] \sim \mathrm{N}\left[\left(\begin{array}{l}
0 \\
0 \\
0
\end{array}\right),\left[\begin{array}{ccc}
\sigma_{b_{o}}^{2} & \sigma_{b_{o} b_{1}} & \sigma_{b_{o} b_{2}} \\
\sigma_{b_{1} b_{o}} & \sigma_{b_{1}}^{2} & \sigma_{b_{1} b_{2}} \\
\sigma_{b_{2} b_{o}} & \sigma_{b_{2} b_{1}} & \sigma_{b_{2}}^{2}
\end{array}\right]\right]
$$
coefficients, respectively

3. Apparently digestible $\mathrm{N}(\%)$

$$
Y_{i j}=\left(B_{o}+B_{o(m)} z_{i}+b_{o i}\right)-\frac{100 \times\left(B_{1}+B_{1(m)} z_{i}+b_{1 i}\right)}{X_{i j}}+r_{i j},
$$

where $B_{0}$ is a coefficient associated with true digestibility and $B_{1}$ is a coefficient associated with the nondietary fecal $\mathrm{N}$

4. Urinary $\mathrm{N}$ (g of $\mathrm{N} / \mathrm{kg}$ of $\mathrm{BW}^{0.75}$ )

$Y_{i j}=\left(B_{o}+B_{o(m)} z_{i}+b_{o i}\right)+\left(B_{1}+B_{1(m)} z_{i}+b_{1 i}\right) \times N I \times e^{\frac{-3 \times\left(K+K_{(m)} z_{i}+k_{i}\right)}{N I}}+r_{i j}$,

$$
\left[\begin{array}{c}
b_{o i} \\
b_{1 i} \\
k_{i}
\end{array}\right] \sim \mathrm{N}\left[\left(\begin{array}{l}
0 \\
0 \\
0
\end{array}\right),\left[\begin{array}{ccc}
\sigma_{b_{o}}^{2} & \sigma_{b_{o} b_{1}} & \sigma_{b_{o} k} \\
\sigma_{b_{1} b_{o}} & \sigma_{b_{1}}^{2} & \sigma_{b_{1} k} \\
\sigma_{k b_{o}} & \sigma_{k b_{1}} & \sigma_{k}^{2}
\end{array}\right]\right]
$$

where $B_{o}$ is a coefficient associated with basal urinary $\mathrm{N}$ excretion,

$B_{1}$ is a coefficient of the linear response when $\mathrm{N}$ intake $\rightarrow \infty$, and
$K$ is the exponential coefficient of the response to increasing $\mathrm{N}$ intake

$$
\left[\begin{array}{l}
b_{o i} \\
b_{1 i}
\end{array}\right] \sim \mathrm{N}\left[\left(\begin{array}{l}
0 \\
0
\end{array}\right),\left[\begin{array}{cc}
\sigma_{b_{o}}^{2} & \sigma_{b_{o} b_{1}} \\
\sigma_{b_{1} b_{o}} & \sigma_{b_{1}}^{2}
\end{array}\right]\right]
$$

5. $\mathrm{N}$ retention ( $\mathrm{g}$ of $\mathrm{N} / \mathrm{kg}$ of $\mathrm{BW}^{0.75}$ )

$$
Y_{i j}=\left(A+A_{(m)} z_{i}+a_{i}\right)+\left(B+B_{(m)} z_{i}+b_{i}\right) \times\left(1-e^{\left(-\left(K+K_{(m)} z_{i}+k_{i}\right) X_{i j}\right)}\right)+r_{i j}
$$

where $A$ is a coefficient associated with the basal $\mathrm{N}$ excretion when $\mathrm{N}$ intake $=0$, $B$ is a plateau coefficient when $\mathrm{N}$ intake $\rightarrow \infty$, and

$K$ is the exponential coefficient of the response to increasing $\mathrm{N}$ intake

${ }^{1}$ Common across equations: $i=1, \ldots, 27$ or 23 trials for equations [1] and [3] and for equations [2], [4], and [5], respectively; $j=1, \ldots, \mathrm{n}_{i}$ observations; $z_{i}=1$ if milk-fed, 0 if weaned for trial $i ;(\mathrm{m})=$ coefficient associated with the covariate when $z_{i}=1$; capital letters indicate a fixed effect coefficient, lowercase letters indicate random effects; $X_{i j}=\mathrm{N}$ intake; and $r_{i j}=$ residual error term $\sim \mathrm{N}\left(0, \sigma_{\mathrm{r}}^{2}\right)$.

are not required to adequately fit the data. One major weakness of an increasing exponential function, and any function that increases multiplicatively, is that at higher levels of NI, predicted N losses can surpass NI. Furthermore, if NR approaches a maximum after which no further gains are possible, UN should eventually closely parallel NI, which is an impossibility with the exponential function. Finally, as NI approaches zero, the slope of the UN excretion curve should approach zero as $\mathrm{N}$ conservation approaches a maximum and UN excretion approaches basal levels. This situation would be represented mathematically by an equation possessing a sigmoid-shaped slope with a lower asymptote of zero and an upper asymptote approximating true digestibility of NI. Equation [4] (Table 1) is proposed as a means to meet each of these theoretical and statistical criteria after extension with covariate and random effect variables. This equation approaches linearity, with a slope of $B_{1}$, as NI approaches infinity and dUN/dNI approaches zero as NI approaches zero. The excretion of UN accelerates maximally in response to $\mathrm{NI}$ at the inflection point of dUN/dNI, when NI equals $k$. Basal $\mathrm{UN}$ is represented by $B_{o}$ when NI approaches zero, although, because this equation is undefined when NI equals exactly zero and NI cannot be negative, a lower bound of NI $>0$ exists. 
Retained N was characterized by using a nonlinear asymptotic model (Robbins et al., 1979); however, a quadratic function also fit the data well in the range of NI analyzed. Because it is generally assumed that a growth response cannot decline at increased input of the limiting nutrient beyond the maximal response, the asymptotic exponential function, after adjusting for trial and dietary covariate effects, is reported and is shown in equation [5] (Table 1).

The adequacy of the variance-covariance matrix of the random effects was assessed for its contribution to model fit relative to the number of additional parameters by the Schwarz-Bayesian information criterion. Differences were considered statistically significant at $P<0.05$. When the diet covariate tested to be not different from zero at $P>0.10$, a model was fit by using a common regression coefficient for both the milk-fed and weaned dietary groups. The assumption of normality was assessed by using the normal probability plot correlation coefficient test (Filliben, 1975). Homoskedasticity of residuals and the presence of outliers were evaluated by assessing the Studentized residual vs. predicted response plot with outliers defined and removed when Studentized residuals were $>3$ standard deviations ( $<2 \%$ of observations across all analyses). The assumption that variances of each group (i.e., milk-fed or weaned) were statistically equivalent was assessed by using an exact $F$-test for each dependent variable. Because a large proportion of the variation associated with mixed modeling can be associated with the random effects, it was considered to be valuable to assess the variation that could be accounted for by the whole mixed model $\left(\mathrm{R}_{\text {Mixed }}^{2}\right)$ as well as the variation that could be attributed to the fixed effects $\left(R_{\text {Fixed }}^{2}\right)$. These coefficients were calculated by including the squared residual produced by the mixed procedure for $\mathrm{R}_{\text {Mixed }}^{2}$ or as the squared difference between the observed value and that predicted from the equations presented below for $\mathrm{R}_{\text {Fixed. }}^{2}$. Because the parameters estimated and the relationships observed from the mixed modeling methodology are more valuable to the entire population from which the trials were sampled than those in fixed effect analyses, the figures present the dependent variable of interest after adjusting for random effects of trial (StPierre, 2001), except where indicated.

\section{RESULTS AND DISCUSSION}

\section{General Considerations}

The stipulation that the experimental objective was to study the effects of altering NI in otherwise balanced rations was included so that all of the data analyzed were collected with the same purpose in mind. This was implemented in an attempt to minimize the variation that may be associated with other nutrient intakes because each of the diets was formulated to meet these requirements, even though these nutrient intakes were not identical between trials. This stipulation should also isolate NI apart from alterations in other nutrient intakes, with the exception of whatever nutrient is exchanged for NI, which also limits the interpretation and the inferences to changes in NI.

Using total NI, as opposed to an alternative expression related to protein quality (e.g., metabolizable protein), may lead to enhanced variability in responses to additional NI. Most experiments did not report an estimate of protein quality and many gave insufficient data to allow an estimate to be calculated confidently. Furthermore, $\mathrm{N}$ can enter and leave the digestive tract at virtually all sites along its length. Although the nutritional requirement is for AA and the site of absorption is the small intestine, the great majority of data in growing dairy heifers is for total tract $\mathrm{N}$ digestibility. For this reason, responses to additional NI and extrapolated basal $\mathrm{N}$ losses were evaluated in response to total NI.

It is well established that many metabolic transformations and degrees of physiological regulation are associated with $\mathrm{N}$ utilization and partitioning in both digestive and postdigestive processes in the ruminant animal. In the current analysis, however, we have attempted to describe animal responses to alterations in NI by using simplified mathematical representations on a whole-animal input-output basis, with the understanding that these observations are the sum of many physiological processes. However, these input-output mathematical representations can be of both practical and scientific value if an adequate description of the data can be achieved with physiologically identifiable parameters.

Finally, the range of time encompassed by papers in the current analysis is considerable ( $>50 \mathrm{yr}$ ). This time also corresponds to a tremendously rapid rate of genetic improvement for lactation performance and mature weight. The possibility therefore exists that the responses analyzed also depend on the year of study; however, limiting the years of study to only the most recent research would have severely diminished the number of experiments that would have been eligible for analysis. It is not altogether clear, however, whether the weight-specific inputs [NI and ME intake (MEI) per $\mathrm{BW}^{0.75}$ produce differences in the weight-specific responses to a level detectable in this type of analysis. For these reasons, data from all years were analyzed and reported. 


\section{Scaling}

As indicated previously, intake and response data were scaled to enable comparison between animals differing greatly in BW. Typically, FN excretion and $\mathrm{ADN} \%$ are considered related to DMI, and by implication, to the $\mathrm{N}$ concentration of the diet (Mitchell, 1924). However, it is likely that part of nondietary $\mathrm{N}$ excretion into feces is simply an alternative mode of $\mathrm{N}$ excretion derived from tissue metabolism (Orskov and Mac Leod, 1982). This creates the possibility that FN would be better related to BW, as noted from data compiled for calves by Lofgreen and Kleiber (1953). To test for this possibility, an initial analysis was conducted in which variation from diet source, DMI, and BW could be determined and the most appropriate variable for scaling assessed. Within this data set, $\mathrm{FN}$ and $\mathrm{ADN} \%$ were more closely related to DMI $(P<0.001)$ than BW $(P>$ 0.652 ) when both variables were in the model, supporting a previous report (Schneider, 1934). Thus, FN, $\mathrm{ADNI}$, and NI are expressed relative to DMI in the current analysis when $\mathrm{N}$ digestion is discussed.

Urinary $\mathrm{N}$ and $\mathrm{NR}$ are commonly scaled to $\mathrm{BW}^{0.75}$ because of the relationship between the so-called endogenous $\mathrm{N}$ metabolism (Smuts, 1935) and basal energy metabolism and because basal energy metabolism varies according to $\mathrm{BW}^{0.75}$ in mature animals across species (Kleiber, 1932). To determine whether this base was appropriate for intraspecific comparisons of $\mathrm{N}$ metabolism in growing cattle in the current analysis, a fixed effects, unscaled alteration of equation [4] was fit to allow the BW exponent associated with the intercept to vary. On the basis of the results of this preliminary analysis, when the exponent was fit objectively, a scaling factor of $\mathrm{BW}^{0.573( \pm 0.093)}$ would be recommended. This value approximates the average exponent of $\mathrm{BW}^{0.58}$ found by Brody (1945) for resting metabolic rate in growing Holstein $\left(\mathrm{BW}^{0.60}\right)$ and Jersey $\left(\mathrm{BW}^{0.56}\right)$ cattle as well as the value of $\mathrm{BW}^{0.58}$ more recently reported by Freetly et al. (2003) for growing crossbred heifers. The exponent parameter was not significantly different from $0.75(P>0.062)$; the fit of the model also was not diminished substantially when the exponent was fixed at 0.75 . For these reasons, and to maintain consistency with other literature results, UN and NR data are expressed relative to $\mathrm{BW}^{0.75}$.

\section{N Digestion}

The effect of NI on ADNI has been investigated several times in the past for preruminating and functioning ruminants. Typical analyses include simple linear, multiple linear, and nonlinear regression approaches including various factors thought to be involved with digestion of N. Simple linear regressions in the form of

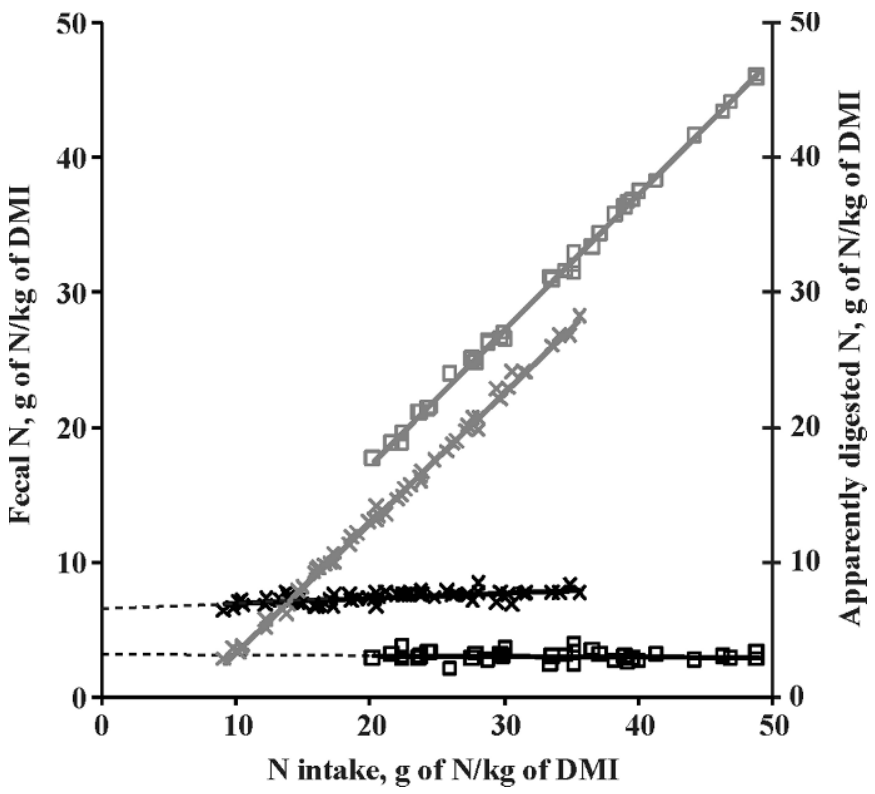

Figure 1. Relationship between dietary N intake (NI, g/kg of DMI) and the distribution of $\mathrm{N}$ that was apparently digested or that appeared in the feces of growing dairy cattle fed milk ( $\square$ ) or weaned $(\times)$, after adjustment for random trial effects. Extrapolations are indicated by broken lines. Parenthetical values associated with the equation are SE. Intercept $(P<0.001)$ and slope $(P<0.008)$ coefficients differed for both apparently digestible $\mathrm{N}$ intake (ADNI) and fecal $\mathrm{N}$ (FN) excretion. The milk-fed ADNI slope coefficient was not different from 1, and the FN slope coefficient was not different from zero $(P$ $>0.691$ ). Apparently digestible $\mathrm{N}$ intake, milk-fed: $\mathrm{ADNI}=-3.05$ $( \pm 0.40)+1.004( \pm 0.009) \times \mathrm{NI}$. Apparently digestible N intake, weaned: $\mathrm{ADNI}=-6.51( \pm 0.31)+0.964( \pm 0.011) \times \mathrm{NI} . \mathrm{R}_{\text {Mixed }}^{2}=0.999 ; \mathrm{R}_{\text {Fixed }}^{2}=$ 0.994 . Fecal N, milk-fed: FN $=3.05( \pm 0.40)-0.004( \pm 0.009) \times \mathrm{NI}$. Fecal N, weaned: $\mathrm{FN}=6.51( \pm 0.31)+0.036( \pm 0.011) \times \mathrm{NI}$. $\mathrm{R}_{\text {Mixed }}^{2}=$ $0.975 ; \mathrm{R}_{\text {Fixed }}^{2}=0.859$.

equation [1] relating NI to ADNI (both as $\mathrm{g} / \mathrm{kg}$ of DMI) are frequently conducted to obtain estimates of true digestibility (TD, linear slope) and nondietary FN (NDFN, intercept). The term NDFN is defined in the current analysis as the amount of FN excreted when none is consumed (by extrapolation) and is not meant to imply the specific metabolic origin of this $\mathrm{N}$, only that, by definition, it does not come directly from the diet. The utility of this definition and the applicability of the estimated NDFN to diets containing $\mathrm{N}$ depends on the assumption that the quantity of NDFN entering the feces remains constant and independent of the amount of $\mathrm{N}$ consumed. This assumption is briefly addressed below, but it is generally believed that in nonruminants the results of feeding protein-free diets or linear regression approaches represent a minimum value of NDFN that may increase as protein intake increases (Stein et al., 2007).

Results of this analysis are shown in Figure 1 and reveal considerable differences in NDFN between milk- 
fed and weaned cattle and smaller, although significant, differences in predicted TD. Because less than complete digestion would be indicated by FN increasing as NI increases, milk-fed animals completely digested the $\mathrm{N}$ provided, as indicated by a slope of ADNI vs. NI that did not differ from unity $(P>0.691)$ and constant FN at all levels of NI. These results are consistent with the results of an experiment conducted with multicannulated Holstein calves in which ileal flows of $\mathrm{CP}$ were not affected whether calves were fed a protein-free diet or increasing levels of milk protein (Montagne et al., 2000). This view also has been expressed previously (Cunningham and Brisson, 1957; Roy, 1970); however, other experiments have suggested less than complete digestibility of milk proteins based on different techniques (e.g., 93.5\%; Lofgreen and Kleiber, 1953).

Likewise, very high levels of TD were found for weaned cattle. The TD in the current analysis of $96.4 \%$ was higher than that found in other work based on regression techniques; previous estimates range from 87\% (Moran and Vercoe, 1972), to 89\% (Griffiths and Connolly, 1977), to 93\% (Holter and Reid, 1959; Van Soest, 1967). All of these results are considerably higher than the real digestibility of $75 \%$ observed by Ouellet et al. (2002) using the ${ }^{15} \mathrm{~N}$ dilution technique in lactating dairy cows. Although the TD is generally found to be very high, the possibility is not precluded that some $\mathrm{N}$ sources can individually have a lower TD (Kononoff et al., 2007), as is especially the case with heat-damaged silages (Van Soest and Mason, 1991).

The NDFN was estimated to be $3.05 \mathrm{~g} / \mathrm{kg}$ of DMI for milk-fed calves in the current analysis, but a fairly large range exists for estimates of NDFN based on a variety of techniques in other studies. For instance, when proteinfree diets were fed, calves were found to excrete 3.34 (Cunningham and Brisson, 1957) or $4.27 \mathrm{~g} / \mathrm{kg}$ of DMI (Blaxter and Wood, 1951a); regression analysis resulted in $2.24 \mathrm{~g} / \mathrm{kg}$ of DMI (Donnelly and Hutton, 1976), and ${ }^{32} \mathrm{P}$-labeled CN yielded $2.7 \mathrm{~g} / \mathrm{kg}$ of DMI (Lofgreen and Kleiber, 1953). Davis and Drackley (1998) adopted a value of $2.2 \mathrm{~g} / \mathrm{kg}$ of DMI in their calculation of milk-fed calf $\mathrm{N}$ requirements based on the results of experiments using both $\mathrm{N}$-free diets and extrapolation procedures; the NRC (2001) used a value of $1.9 \mathrm{~g} / \mathrm{kg}$ of DMI.

The ADN\% was substantially lower than the predicted TD observed for weaned dairy cattle (Figure 2) because of a large contribution of NDFN toward FN excretions. The NDFN predicted for weaned, growing cattle was $6.51 \mathrm{~g} / \mathrm{kg}$ of DMI. This value corresponds closely to those reported from some experiments (Mugerwa and Conrad, 1971; Stallcup et al., 1975); however, it is higher than most, which averaged $4.7 \mathrm{~g} / \mathrm{kg}$ of DMI in a review by Swanson (1977). In contrast to the constant level of FN excretion observed in milk-fed calves,

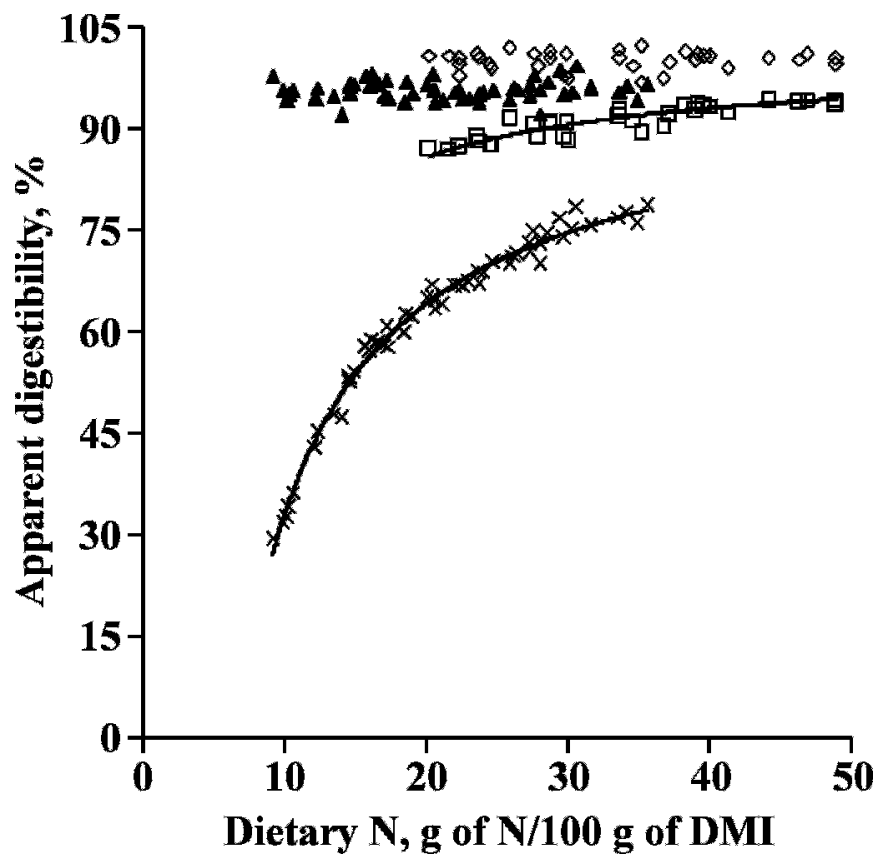

Figure 2. Response of apparently digestible $\mathrm{N}(\mathrm{ADN}, \%)$ to $\mathrm{N}$ intake (NI, g/kg of DMI) in growing dairy cattle fed milk ( $\square$ ) or weaned $(\times)$, after adjustment for random trial effects. Parenthetical values associated with the equation are SE. The milk-fed and weaned regression equations were different because of differences in nondietary fecal N (NDFN, $P<0.001$ ) and predicted true digestibility (TD, $P<$ 0.004). Predicted TD, adjusted for overall (fixed) and between-trial (random) differences in NDFN, are included above the respective regression lines: milk-fed $(\diamond)$ or weaned $(\boldsymbol{\Delta})$. Milk-fed: $\mathrm{ADN} \%=$ $100.26( \pm 1.11)-100 \times 2.90( \pm 0.42) / \mathrm{NI}$. Weaned: ADN\% $=95.75( \pm 0.91)$ $-100 \times 6.35( \pm 0.26) /$ NI. $R_{\text {Mixed }}^{2}=0.995 ; R_{\text {Fixed }}^{2}=0.954$.

more FN was excreted at higher levels of NI in weaned cattle $(P<0.001)$. From the results of the current analysis, it can be calculated that at the lowest level of NI, NDFN accounts for $95 \%$ of $\mathrm{FN}$ and at the highest level of NI, NDFN accounts for $82 \%$ of FN, assuming NDFN remains constant.

This assumption has been questioned, however, based on results of several experiments using a variety of techniques to assess small intestinal endogenous protein flows. When assessing the constancy of endogenous $\mathrm{N}$ excretion in the porcine small intestine by using the enzyme-hydrolyzed protein method, Hodgkinson et al. (2000) found that as intake of peptides increased, flow of endogenous N and most AA increased. Swanson et al. (2004) also indicated that abomasal CN infusion enhanced secretion of several pancreatic exocrine proteins, although coinfusion with starch hydrolysate did not produce this response. In contrast, de Lange et al. (1989) found providing AA parenterally reduced endogenously derived protein by $32 \%$. It also has been shown that morphology and enzymatic activities of the small intestine were negatively influenced by the protein-free 
diet and, generally, more positive outcomes associated with these variables were related to increasing protein concentration in a milk protein-based diet (Lalles et al., 2001). It is possible that a balance exists between the contribution of digestive enzyme secretion and small intestinal mucosa protein to endogenous protein, which may be differentially affected by protein status. Because for milk-fed calves FN output was not different, the net result of these changes was that the quantity of endogenous protein was not different, but the composition and source of this protein may have been different. An imbalance in either or both of these characteristics and an unchanged or reduced level of reabsorption would therefore lead to an increasing NDFN with increasing NI and would have the effect of increasing TD above the determined values.

The previously addressed experiments relate to the animal contribution to small intestinal endogenous $\mathrm{N}$ flow, which would be anticipated to contribute the majority of NDFN in preruminant calves. Several experiments have shown that a considerable proportion of NDFN in functioning ruminants is unabsorbed bacterial $\mathrm{N}$ originating in the rumen or cecum (Mason, 1969), which likely contributes substantially toward the increased levels of NDFN observed for weaned cattle. However, even in milk replacer-fed calves there appears to be a substantial contribution of bacterial $\mathrm{N}$ toward ileal $\mathrm{N}$ flow. It was mentioned previously that ileal $\mathrm{N}$ was not different for calves fed a protein-free diet or 3 increasing levels of milk protein (Montagne et al., 2000). In this study, the proportion of ileal $\mathrm{N}$ predicted to be bacterial $\mathrm{N}$ increased from approximately $27 \%$ for the diet containing $28 \% \mathrm{CP}$ to $50 \%$ for the protein-free diet, although bacterial $\mathrm{N}$ was not identified in jejunal or duodenal samples. Ruminal bacterial $\mathrm{N}$ has been reported to have a TD of $81 \%$ (Storm et al., 1983). Thus, even ruminal bacterial $\mathrm{N}$, which would be available for small intestinal digestion, is not completely absorbed, and $\mathrm{N}$ incorporated into bacterial protein distal to or in the ileum would not be absorbed as AA $\mathrm{N}$ in appreciable quantities. From the results of the current analysis, it was concluded that across a large range of dietary and environmental conditions, total tract TD of $\mathrm{N}$ in growing dairy cattle is very high and that all $\mathrm{N}$ in the feces of milk-fed calves and a great majority of the $\mathrm{N}$ in the feces of weaned cattle is not directly of dietary origin.

\section{UN}

Urine $\mathrm{N}$ excretion is presented in Figure 3 in relation to NI (both as $\mathrm{g} / \mathrm{kg}$ of $\mathrm{BW}^{0.75}$ ). Calves fed milk were predicted to excrete $0.278 \mathrm{~g} / \mathrm{kg}$ of $\mathrm{BW}^{0.75}$ when NI approaches zero as an estimate of basal UN excretion. The intercept for weaned cattle was $0.123 \mathrm{~g} / \mathrm{kg}$ of

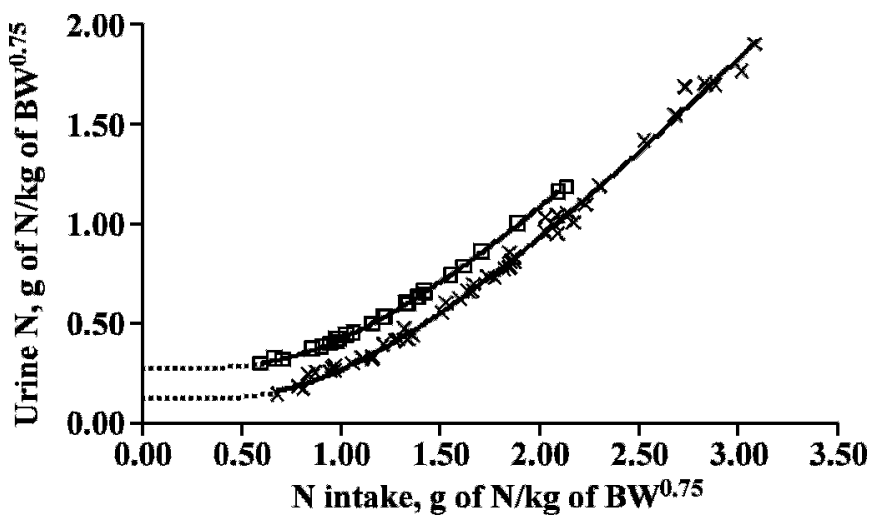

Figure 3. Relationship between $\mathrm{N}$ intake (NI, g/kg of $\left.\mathrm{BW}^{0.75}\right)$ and urinary $\mathrm{N}\left(\mathrm{UN}, \mathrm{g} / \mathrm{kg}\right.$ of $\left.\mathrm{BW}^{0.75}\right)$ in growing dairy cattle fed milk ( $\square$ ) or weaned ( $\mathrm{X}$ ), after adjustment for random trial effects. Extrapolations are indicated by broken lines. Parenthetical values associated with the equation are SE. The milk-fed and weaned regression equations possessed different intercepts $(P<0.001)$; however, slope coefficients were not different individually or collectively $(P>0.10)$. Milkfed: $\mathrm{UN}=0.278( \pm 0.025)+1.146( \pm 0.128) \times \mathrm{NI} \times e^{\frac{-3 \times[0.698( \pm 0.097)]}{\mathrm{NI}}}$. Weaned: $\mathrm{UN}=0.123( \pm 0.036)+1.146( \pm 0.128) \times \mathrm{NI} \times e^{\frac{-3 \times[0.698( \pm 0.097)]}{\mathrm{NI}}} \cdot \mathrm{R}_{\text {Mixed }}^{2}=$ $0.992 ; R_{\text {Fixed }}^{2}=0.750$.

$\mathrm{BW}^{0.75}$; these estimates of basal UN excretion were significantly different from each other $(P<0.001)$. Brody (1945) found that an interspecies relationship existed between basal $\mathrm{N}$ excretion and a large range of mature animal BW and could be represented as $0.146 \mathrm{~g} / \mathrm{kg}$ of $\mathrm{BW}^{0.72}$. Blaxter and Wood (1951a) observed basal N excretion of $0.194 \mathrm{~g} / \mathrm{kg}$ of BW $\mathrm{BW}^{0.75}$ in 30-kg Ayrshire milkfed calves, and Cunningham and Brisson (1957) obtained $0.186 \mathrm{~g} / \mathrm{kg}$ of $\mathrm{BW}^{0.72}$ in $35-$ to $40-\mathrm{kg}$ milk-fed Ayrshire and Holstein calves. In ruminating cattle fed virtually $\mathrm{N}$-free diets containing both roughage and concentrates, Kehar et al. (1943) observed UN excretion of $0.083 \mathrm{~g} / \mathrm{kg}$ of BW $\mathrm{BW}^{0.75}$. Swanson (1977) reviewed maintenance UN losses for cattle and determined that the best relationship was $0.440 \mathrm{~g} / \mathrm{kg}$ of $\mathrm{BW}^{0.5}$ for $\mathrm{BW}$ ranging from 30 to $600 \mathrm{~kg}$. Each of the previous estimates was based on $\mathrm{N}$-free or very low $\mathrm{N}$ diets fed for various durations, which can have a negative impact on the rumen microbial population in ruminating cattle and can cause diarrhea, shivering, and reduced performance in calves (Blaxter and Wood, 1951a; Cunningham and Brisson, 1957). Orskov and MacLeod (1982) maintained growing steers at zero NI by using an intragastric infusion technique designed to separate wholeanimal responses from metabolism in the rumen. With this procedure, UN excretions of between 0.295 and $0.426 \mathrm{~g} / \mathrm{kg}$ of $\mathrm{BW}^{0.75}$ were observed in growing steers when energy was supplied as VFA but when no $\mathrm{N}$ was infused. The NRC (2001) used $0.2 \mathrm{~g} / \mathrm{kg}$ of BW $\mathrm{BW}^{0.75}$ (Davis and Drackley, 1998) in its protein requirement calcula- 
tions for milk-fed calves and $0.440 \mathrm{~g} / \mathrm{kg}$ of $\mathrm{BW}^{0.5}$ (Swanson, 1977) for weaned cattle.

Use of a regression approach to extrapolate basal UN excretion has been criticized as inappropriate for ruminating cattle because high-protein feeds differ in solubility. Therefore, this may differentially affect UN excretion at high NI, depending on the $\mathrm{N}$ source, and lead to variable estimates of basal $\mathrm{N}$ excretion (Swanson, 1977). This seems to be a valid criticism of the approach; however, it can be inferred from the consistency of the results in the current analysis spanning a large variety of feeds and experimental conditions that the implications of this concern are smaller than believed.

Although the range of NI was considerably greater for weaned cattle, the slope coefficients were not different individually or collectively $(P>0.10)$ from those for the milk-fed calves. The linear coefficient exceeded unity at the extrapolated infinite NI; however, at the highest level of NI represented within this data set, the slope of the UN vs. NI response was 0.967, a level closely approximating TD observed in the analyses previously addressed. Thus, as NI approaches the highest level occurring in the current analysis, UN parallels truly digestible NI. The coefficient $k$ allows curvature in the UN excretion response between the linear response at maximum NI and the intercept, where the slope of the response curve approaches zero. This coefficient equals the NI for which the excretion of UN is maximally accelerating in response to dietary NI. This response coefficient was 0.698 and did not differ between milk-fed calves and weaned cattle. Within the range of NI included in the current analysis, there appears to be little differential effect of diet type in response to additional NI; the difference arises from a consistently lower level of UN excretion for weaned cattle. A consistently lower level of UN excretion for milk-fed calves may correspond to the previously emphasized microbial capture of dietary NI in the lumen of the gastrointestinal tract of the weaned ruminant (Mason, 1969). Another possible explanation for the reduced UN excretion in the weaned cattle is that there is enhanced recycling of urea $\mathrm{N}$ with subsequent microbial capture and FN excretion (Marini et al., 2004; Sunny et al., 2007). This would potentially lead to lower urinary urea excretion in weaned ruminants because this pathway would likely be minimally present in milk-fed calves (Hayashi et al., 2006). This result would tend to agree with the higher UN values produced by use of the intragastric infusion technique, which results in limited production of feces and minimal $\mathrm{N}$ capture in the lumen of the gastrointestinal tract (Orskov and Mac Leod, 1982). Milk-fed calves from the current analysis approached the minimum UN excretion reported by the use of this technique; however,

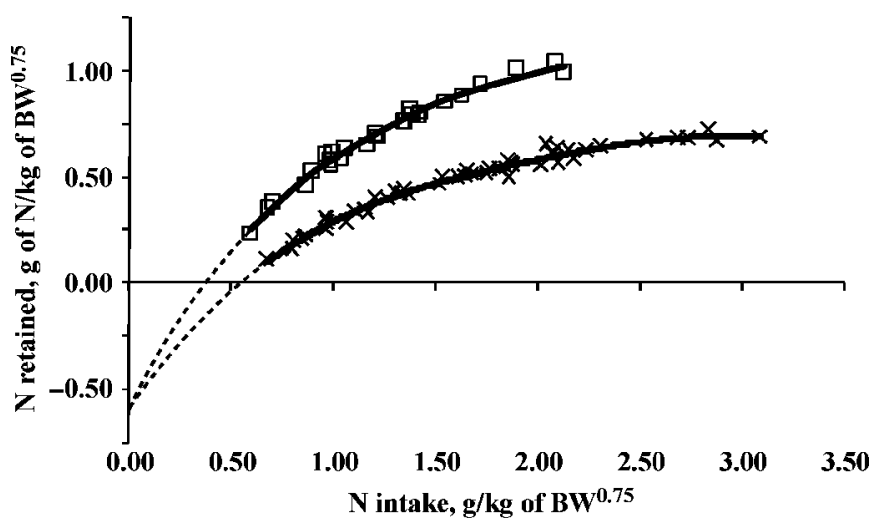

Figure 4. Relationship between $\mathrm{N}$ intake (NI, g/kg of $\mathrm{BW}^{0.75}$ ) and $\mathrm{N}$ retained (NR, g/kg of $\mathrm{BW}^{0.75}$ ) in growing dairy cattle fed milk ( $\square$ ) or weaned $(\times)$, after adjustment for random trial effects. Extrapolations are indicated by broken lines. Parenthetical values associated with the equation are SE. The milk-fed and weaned regression equations were different because of different plateaus $(P<0.001)$; intercepts and exponential coefficients did not differ between diet types $(P>0.50)$ and were fit by using common coefficients. Milk-fed: $\mathrm{NR}=$ $-0.600( \pm 0.110)+1.799( \pm 0.134) \times\left[1-e^{-1.067( \pm 0.167) \times \mathrm{NI}}\right]$. Weaned: $\mathrm{NR}=$ $-0.600( \pm 0.110)+1.341( \pm 0.126) \times\left[1-e^{-1.067( \pm 0.167) \times \mathrm{NI}}\right] . R_{\text {Mixed }}^{2}=0.995$. $\mathrm{R}_{\text {Fixed }}^{2}=0.603$.

neither group achieved this high level of basal UN excretion. In fact, 0.633 and $1.087 \mathrm{~g} / \mathrm{kg}$ of $\mathrm{BW}^{0.75}$ must be consumed by milk-fed and weaned cattle for UN excretion of $0.300 \mathrm{~g} / \mathrm{kg}$ of $\mathrm{BW}^{0.75}$, which was approximately the lowest level observed by Orskov and MacLeod (1982). Because it has been shown in several species that urea can be removed from circulation and contribute to FN at the expense of UN and that this proportion can be changed by dietary means (Orskov et al., 1970; Mosenthin et al., 1992), considering UN excretion in isolation from FN excretions may be erroneous.

\section{Retained N}

Retained N is related to NI in Figure 4, fit according to equation [5], where, in the terminology used here, $-A$ is the extrapolated total $\mathrm{N}$ excreted when none is consumed (i.e., total basal $\mathrm{N}$ excretion in both feces and urine), $A+B$ is the predicted maximum level of NR, and $k$ is associated with the rate of increase from $A$ to $A+B$. Coefficient $A$ did not differ between milk-fed and weaned cattle $(P>0.20)$, so a model was fit with a common value between groups. This practice predicted that basal $\mathrm{N}$ excretion from the combination of feces and urine was $0.600 \mathrm{~g} / \mathrm{kg}$ of $\mathrm{BW}^{0.75}$ for both dietary groups and that maximum NR was 1.199 and $0.741 \mathrm{~g} /$ $\mathrm{kg}$ of $\mathrm{BW}^{0.75}$ for the milk-fed and weaned group, respectively. The coefficient $k$ was not significantly different between dietary groups, indicating that, because 
weaned cattle retain less $\mathrm{N}$ per $\mathrm{kg}$ of $\mathrm{BW}^{0.75}$, weaned cattle are less efficient in utilizing dietary $\mathrm{N}$ and are less responsive to alterations in dietary $\mathrm{N}$ content than milk-fed cattle.

It is clear from the low $\mathrm{R}_{\text {Fixed }}^{2}$ that a considerable proportion of variability is unexplained by NI alone, as would be expected considering the number of nutritional and environmental factors that can contribute to enhancing or reducing NR. Considering that NR may be affected by dietary energy (Balch, 1967) and BW (Blaxter et al., 1966; Graham and Searle, 1972) and within each experiment these parameters varied little, it is possible that including a random trial effect may mask this source of important biological variation. To test this possibility, equation [4] was expanded to include parameters associated with $\mathrm{BW}^{0.75}$ and $\ln (\mathrm{MEI})$ affecting the rate and extent of NR and DMI affecting basal $\mathrm{N}$ excretions. If not reported in the paper, MEI was calculated by using published values for the individual feedstuffs consumed ( $\mathrm{n}=1$ or 2 experiments for the milk-fed or weaned group, respectively) or, if reported, from converting digestible energy intake by using published conversion factors (Davis and Drackley, 1998; NRC, 2001; $\mathrm{n}=4$ or 3 experiments for the milk-fed or weaned group, respectively). To determine the most parsimonious model relating $\mathrm{BW}^{0.75}$, $\ln (\mathrm{MEI}), \mathrm{NI}, \mathrm{DMI}$, and diet type, a backward elimination search procedure was used, with Mallows' Cp (Mallows, 1973) used as the decision criteria for variable inclusion. Each of $\mathrm{BW}^{0.75}, \ln (\mathrm{MEI})$, and DMI were highly significant, and when including these additional variables, the random effects associated with trial became highly insignificant $(P>0.90)$.

Fitted results of this effort are shown in Figure 5 for the approximate range of NI, BW, and 3 representative MEI occurring in this data set (mean MEI $\pm 2 \times \mathrm{SD}$ ). The reduced model shown fit the data well, as indicated by a high $R^{2}$ of 0.941 with 8 estimated parameters; it accounted for $98 \%$ of the variation explainable by the full model containing 20 coefficients and provided a substantially better fit than the minimum model containing 3 coefficients $\left(\mathrm{R}^{2}=0.438\right)$. The $\ln (\mathrm{MEI})$ was included as a simple means to account for a diminishing returns response to additional dietary energy, as opposed to a linearly increasing function. This procedure was used previously to relate the effects of energy on NR in sheep (Walker and Norton, 1971) and in attempting to determine the $\mathrm{N}$ requirement for $\mathrm{N}$ balance in human subjects (Rand et al., 2003).

Predicted NR was higher for milk-fed calves at all levels of NI and for animals fed higher MEI and possessing lower BW for all NI above zero. At lower levels of MEI, higher NI was required to obtain $\mathrm{N}$ balance $(\mathrm{NR}=0)$. Likewise, at lower MEI, lower levels of NR



Figure 5. Fitted relationships between $\mathrm{N}$ intake (NI, g/kg of $\left.\mathrm{BW}^{0.75}\right), \mathrm{N}$ retained $\left(\mathrm{NR}, \mathrm{g} / \mathrm{kg}\right.$ of $\left.\mathrm{BW}^{0.75}\right)$, and $\mathrm{BW}(\mathrm{kg})$ in growing dairy cattle fed milk ( 40 to $80 \mathrm{~kg}$ ) or weaned ( $>80 \mathrm{~kg}$ ) at $3 \mathrm{ME}$ intake levels $\left(0.55\right.$, blue; 0.81 , red; 1.06 , yellow; MJ of ME/kg of $\left.\mathrm{BW}^{0.75}\right)$. Dry matter intake $\left(\mathrm{kg} / \mathrm{kg}\right.$ of $\left.\mathrm{BW}^{0.75}\right)$ affected the intercept, so this parameter was fixed to approximately reflect predicted differences in basal excretion between milk-fed and weaned cattle ( 0.30 and 0.65 $\mathrm{g} / \mathrm{kg}$ of $\mathrm{BW}^{0.75}$, respectively). Responses are predicted and approximate the ranges of data entering the analysis that were used to establish the equation, with the exception of the extrapolations to zero NI. The model was fit to include the fewest parameters, with no random trial effects because these were highly insignificant. Parenthetical values associated with the equation are $\mathrm{SE} . \mathrm{NR}=-0.300$ $( \pm 0.181)-7.143( \pm 1.537) \times \mathrm{DMI}+[2.231( \pm 0.150)-0.010( \pm 0.001) \times$ $\left.\mathrm{BW}^{0.75}+1.514( \pm 0.273) \times \ln (\mathrm{MEI})-0.011( \pm 0.004) \times \mathrm{BW}^{0.75} \times \ln (\mathrm{MEI})\right]$ $\times\left\{1-e^{\left[-\left(0.676( \pm 0.141)+0.016( \pm 0.004) \times \mathrm{BW}^{0.75}\right) \times \mathrm{NI}\right]}\right\} . \mathrm{R}_{\mathrm{Fixed}}^{2}=0.941$.

were predicted to be attainable for similar levels of NI. As MEI increased, less NI was required to obtain N balance and greater levels of NR were predicted to be possible at similar levels of NI. The inverse relationship between NI and MEI required to obtain zero NR has been demonstrated previously in growing, milk-fed lambs in which the energy required for $\mathrm{N}$ balance was increased as the $\mathrm{N}$ level in feed was reduced (Walker and Norton, 1971). Likewise, weanling pigs maintained a constant BW (5 to $6 \mathrm{~kg}$ ) for several 40-d periods when alternating between a high-ME, low-N diet or low-ME, high-N diet (Miller and Payne, 1962). Observations of the current analysis are also consistent with the growth data of Gerrits et al. (1996) for milk-fed calves and Ortigues et al. (1990) for growing heifers, and with the infusion studies of Schroeder et al. $(2006 \mathrm{a}, \mathrm{b})$ for growing steers, showing that the NR response to additional NI can be enhanced by increasing energy intake, that is, increased efficiency of $\mathrm{N}$ utilization.

This result contrasts, however, with observations noted by Bartlett et al. (2006), in which a constant efficiency of $\mathrm{N}$ utilization (0.743) was determined for 
whey protein-fed calves until reaching a point (calves fed $26 \% \mathrm{CP}$ at $1.25 \% \mathrm{BW}$ ) at which ME was considered to limit N deposition. Similar observations also have been shown for milk-fed lambs (Black and Griffiths, 1975), intragastrically infused lambs (Lindberg and Jacobsson, 1990), and growing pigs (Campbell et al., 1984, 1985; Kyriazakis and Emmans, 1992). That is, efficiency of dietary $\mathrm{N}$ utilization remained constant until energy limited NR, after which no additional $\mathrm{N}$ gains were possible in response to NI. In an effort to examine this form of relationship between NI and NR for animals in this data set, a fixed-effect rectilinear regression analysis was conducted, regressing NR against NI and allowing the estimated parameters to vary with $\mathrm{BW}^{0.75}$, $\ln (\mathrm{MEI})$, and diet type as previously described for the diminishing returns, exponential response. The primary result of this analysis demonstrated that the slope of the linear portion of the relationship was affected by diet type, MEI, and $\mathrm{BW}^{0.75}$. Because marginal efficiency of NR was affected in the linear range by ME intake, it cannot be concluded that the protein- and energydependent phases of NR describe these data most adequately. As such, the exponential model was accepted and is used as a basis to discuss responses to changing BW and efficiency of $\mathrm{N}$ utilization.

The declining response of NR to increasing BW was not unexpected based on the diminishing weight-specific growth that occurs as an animal approaches maturity (Brody, 1945). The rate of decline in maximum predicted NR for cattle in the current analysis depended on the level of ME consumed and was not differentially affected by diet type, with the maximum decline in maximum NR occurring for the higher levels of MEI and lower reductions predicted for lower levels of MEI. When MEI was $1.06 \mathrm{MJ} / \mathrm{kg}$ of $\mathrm{BW}^{0.75}$, NR declined by $0.011 \mathrm{~g} / \mathrm{kg}$ of $\mathrm{BW}^{0.75}$ for each unit increase in $\mathrm{BW}^{0.75}$, whereas when MEI was $0.55 \mathrm{MJ} / \mathrm{kg}$ of $\mathrm{BW}^{0.75}$, NR declined by $0.004 \mathrm{~g} / \mathrm{kg}$ of $\mathrm{BW}^{0.75}$. In the analysis of milkfed lambs by Black and Griffiths (1975), maximum NR declined by $0.146 \mathrm{~g} / \mathrm{kg}$ of $\mathrm{BW}^{0.75}$ for each unit increase in $\mathrm{BW}^{0.75}$ at the highest level of MEI investigated. Carr et al. (1977), in an analysis of NR in the pig, determined that maximum NR responded to increasing BW in 2 phases. For BW less than $45 \mathrm{~kg}$, maximum NR declined quadratically with BW, which, if expressed as a linear function of $\mathrm{BW}^{0.75}$, is a $0.129 \mathrm{~g} / \mathrm{kg}$ of $\mathrm{BW}^{0.75}$ decline for each unit increase in $\mathrm{BW}^{0.75}$. After $45 \mathrm{~kg}$ of $\mathrm{BW}$, maximum NR declined by $0.026 \mathrm{~g} / \mathrm{kg}$ of $\mathrm{BW}^{0.75}$ per unit increase in $\mathrm{BW}^{0.75}$ (Carr et al., 1977). More recent work in pigs found that the upper limit to NR $(\mathrm{g} / \mathrm{d})$ in the strain investigated was constant between 25 and $85 \mathrm{~kg}$ of BW; relative NR, however, declined at a rate of 0.08 $\mathrm{g} / \mathrm{kg}$ of $\mathrm{BW}^{0.75}$ for each unit increase in $\mathrm{BW}^{0.75}$ (Moughan et al., 2006).
The rate of decline of NR observed in the current analysis was substantially lower than the rates of decline observed for these other farm animal species; however, given differences in the mature size and rate of maturation between these species, it is not surprising that the pig and the sheep have a greater rate of decline in NR than do cattle, as seen in the current analysis. Other experimental data directly confirm the rates of maximum NR reduction in response to increasing BW observed in this statistical analysis: from maximum levels of NI and MEI and the $2 \mathrm{BW}$ reported by Blaxter et al. (1966), a decline in NR of $0.011 \mathrm{~g} / \mathrm{kg}$ of $\mathrm{BW}^{0.75}$ per unit increase in $\mathrm{BW}^{0.75}$ could be calculated. In the current analysis, a differential effect of diet type and BW could not be detected on the decline in NR and may indicate that the decline in maximum NR was more closely related to developmental cues related to BW than dietary type. This has been confirmed from a more mechanistic perspective for milk-fed pigs (Wray-Cahen et al., 1998; Suryawan et al., 2006), indicating that at least one potential factor influencing this decline is that feeding-induced protein synthesis diminishes because of a reduced responsiveness to insulin with advancing age.

Because no differences were observed in the NR response, the marginal efficiency function (dNR/dNI from the equations in Figure 5) calculated for milk-fed and weaned cattle are not different between nutritional groups. Some support for the validity of this response comes from the analysis of the heavy ( 80 to $240 \mathrm{~kg}$ ) milk-fed calves of Gerrits et al. (1996), in which mean marginal efficiency of retaining NI across weights and intakes was reported to be $26.8 \%$. Using MEI, CP intake, and mean BW reported for those experiments, we calculated a mean marginal efficiency of $31.7 \%$ from the equation associated with Figure 5. The marginal efficiency results of Gerrits et al. (1996) were calculated by using the linear slope coefficients across several levels of NI, whereas the results from the current analysis are an instantaneous estimate of marginal efficiency. Differences in computations may lead to deviations in the estimated marginal efficiencies between methods; however, the similarity in estimates is surprising considering that the maximum BW for milk-fed cattle was $81 \mathrm{~kg}$. This observation would seem to lend some support to a hypothesis that marginal efficiency of using additional NI depends more on development, as indicated by advancing BW, than on being milk-fed or weaned per se.

The GNE, adjusted for random trial effects, is shown in Figure 6 in response to NI. The variability across experiments was considerable, but when this variation was modeled by using the random trial effect to isolate the response to additional NI, a significant curvilinear 


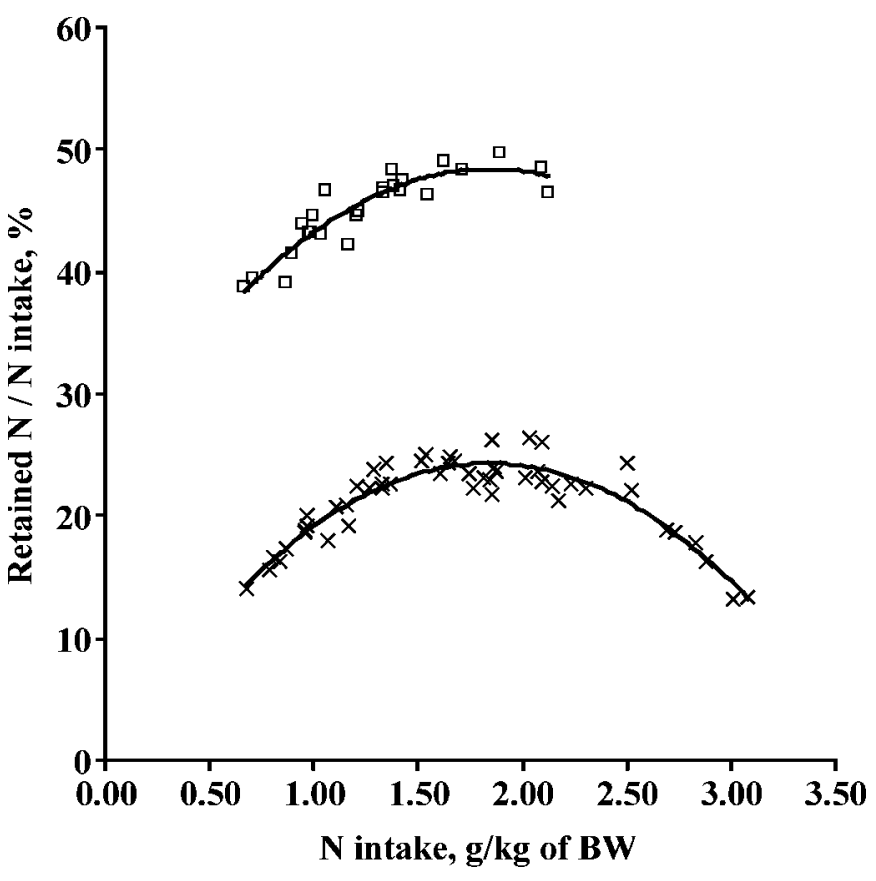

Figure 6. Relationship between $\mathrm{N}$ intake (NI, g/kg of $\mathrm{BW}^{0.75}$ ) and gross $\mathrm{N}$ efficiency (GNE, g of NR/g of NI) in growing dairy cattle fed milk $(\square)$ or weaned $(\times)$, after adjustment for random trial effects. Parenthetical values associated with the equation are SE. The milkfed and weaned regression equations were different $(P<0.001)$ because of differences in the intercept $(P<0.002)$; none of the slope coefficients were different individually $(P>0.15)$ or collectively $(P>$ 0.30 ) and were fit by using common coefficients. Milk-fed: GNE = $0.238( \pm 0.083)+0.268( \pm 0.08) \times \mathrm{NI}-0.073( \pm 0.020) \times \mathrm{NI}^{2}$. Weaned: $\mathrm{GNE}=-0.003( \pm 0.080)+0.268( \pm 0.08) \times \mathrm{NI}-0.073( \pm 0.020) \times \mathrm{NI}^{2}$.

$\mathrm{R}_{\text {Mixed }}^{2}=0.995 ; \mathrm{R}_{\text {Fixed }}^{2}=0.550$.

relationship emerged. Gross N efficiency was greater for milk-fed calves than weaned heifers, but the response to NI did not differ between diet types $(P>$ $0.151)$. From these equations, maximum GNE was predicted to occur when NI was $1.84 \mathrm{~g} / \mathrm{kg}$ of $\mathrm{BW}^{0.75}$ regardless of diet type; however, because the energy and CP density of the rations were greater for milk-fed calves, the relationship between CP concentration and GNE differed significantly between diet types. Maximum GNE occurred at $18.9 \% \mathrm{CP}$ for milk-fed calves, whereas weaned cattle obtained maximum GNE at $14.2 \% \mathrm{CP}$. Thus, although the NI required for maximum GNE was not statistically different between diet types, differences in nutrient density of the rations offered altered the CP concentration at which the maximum GNE was predicted to occur. Another potentially valuable means of expressing CP concentration is relative to the energy density of the diet (Baker, 1986). Expressed in this fashion, assuming $16.74 \mathrm{~kJ}$ of $\mathrm{ME} / \mathrm{g}$ of $\mathrm{CP}$ and $6.25 \mathrm{~g}$ of $\mathrm{CP} / \mathrm{g}$ of $\mathrm{N}$, the maximum GNE occurs when $22.5 \%$ of dietary energy is energy derived from $\mathrm{CP}$ (i.e., MJ of $\mathrm{CP} / \mathrm{MJ}$ of $\mathrm{ME}$ ) for both dietary groups. This value cor- responds closely to the protein-to-energy ratio of $20 \%$ (Campbell et al., 1984), 22\% (Campbell et al., 1985), 23\% (Kyriazakis and Emmans, 1992), and 25\% (Sandberg et al., 2005) where maximum $\mathrm{N}$ efficiency occurred in pigs, and a protein-to-energy of $22 \%$ (Blaxter and Wood, 1951b) to avoid utilizing protein to meet energy requirements in maximally gaining milk-fed calves; however, this value is lower than the theoretically derived optimum protein-to-energy ration of 27\% (Miller and Payne, 1963).

Although the range of NI (as either $\mathrm{g} / \mathrm{kg}$ of $\mathrm{BW}^{0.75}$ or $\mathrm{MJ}$ of CP/MJ of ME) in milk-fed calves did not have a large representation of data beyond the predicted peak level of efficiency, the consistency of response would again support the hypothesis that efficiency of NR responds similarly to additional NI between milk-fed and weaned cattle. This would be a surprising result based on the large portal-drained viscera $\mathrm{NH}_{3}$ flux and $\mathrm{AA}$ utilization for gluconeogenesis in weaned ruminants (Seal and Reynolds, 1993); however, the similarity in UN excretion curves may give additional support to this hypothesis. The similarities in response functions may, however, be partially due to efficiency caused by ruminal metabolism itself, because it has been estimated that the CP-to-ME ratio to maximize rumen microbial protein production in sheep is $19 \% \mathrm{MJ}$ of $\mathrm{CP} /$ $\mathrm{MJ}$ of $\mathrm{ME}$ when $30 \mathrm{~g}$ of microbial $\mathrm{N}$ is produced $/ \mathrm{kg}$ of truly digested OM (Allen and Miller, 1976). Using assumptions presented by Allen and Miller (1976), we could also calculate a value of $19 \% \mathrm{MJ}$ of $\mathrm{CP} / \mathrm{MJ}$ of $\mathrm{ME}$ from the value of $29.74 \mathrm{~g}$ of microbial N/kg of truly digested OM presented by the NRC (Figure 5-4, 2001) to maintain a ruminal $\mathrm{N}$ balance of zero for lactating dairy cows.

Absolute levels of NR and GNE are, however, substantially lower in older and weaned cattle than in younger and milk-fed cattle. The sum of basal $\mathrm{N}$ requirements predicted from linear and exponential extrapolation to zero NI (from Figures 1 and 3) predicted that milk-fed calves would excrete $0.411 \mathrm{~g} / \mathrm{kg}$ of BW $\mathrm{BW}^{0.75}$ and weaned cattle were predicted to excrete $0.649 \mathrm{~g} / \mathrm{kg}$ of $\mathrm{BW}^{0.75}$. Furthermore, it can be calculated based on the results of the current analysis that 32.4 and $81.0 \%$ of basal $\mathrm{N}$ excretions were lost in feces for milk-fed and weaned animals, respectively. Dry matter intake was a variable significantly related to basal $\mathrm{N}$ excretion in the fixed-effect exponential model, and predicts that when $\mathrm{NI}$ is zero, $\mathrm{N}$ is excreted in both urine and feces. When DMI is zero, however, as may be approximated experimentally with intragastric infusion, $0.300 \mathrm{~g} / \mathrm{kg}$ of $\mathrm{BW}^{0.75}$ is predicted to be excreted in urine alone.

Orskov and MacLeod (1982) found in dairy cattle that total $\mathrm{N}$ excretion at zero $\mathrm{N}$ infusion with VFA energy infusion was between 0.308 and $0.429 \mathrm{~g} / \mathrm{kg}$ of $\mathrm{BW}^{0.75}$, 
and more recently, Orskov et al. (1999) found a value of $0.261 \mathrm{~g} / \mathrm{kg}$ of BW $\mathrm{BW}^{0.75}$ when glucose energy was infused but no N was given. Furthermore, Hovell et al. (1987) indicated that a mean value of basal UN excretion for 23 lambs nourished by intragastric infusion of VFA with no NI was $0.356 \mathrm{~g} / \mathrm{kg}$ of $\mathrm{BW}^{0.75}$. These values agree closely with the $0.411 \mathrm{~g} / \mathrm{kg}$ of $\mathrm{BW}^{0.75}$ determined for milk-fed calves based on summing fecal and urinary basal $\mathrm{N}$ excretion and the value of $0.300 \mathrm{~g} / \mathrm{kg}$ of $\mathrm{BW}^{0.75}$ determined with the fixed effects model when DMI is zero. The question arises as to whether a value of the obligate basal $\mathrm{N}$ excretion may be near 0.300 to 0.400 $\mathrm{g} / \mathrm{kg}$ of $\mathrm{BW}^{0.75}$ for growing ruminants. This low level may be attainable only when a small quantity of DM passes through the digestive tract, whereas higher values observed for weaned cattle may arise because of substantially greater $\mathrm{N}$ captured in the lumen of the digestive tract, as has been suggested previously (Orskov, 1992). Results from the current analysis tend to support this view; thus, a weaned animal requires 1.57 times as much NI simply to replace basal losses before additional $\mathrm{N}$ can be utilized for gain.

\section{CONCLUSIONS}

From the figures and equations presented in this analysis, it is clear that the responses in FN and UN are very closely related to NI when expressed relative to DMI and $\mathrm{BW}^{0.75}$, respectively. The majority of $\mathrm{FN}$ does not appear to be directly of dietary origin, but likely a mixture of bacterial and endogenous $\mathrm{N}$ trapped or excreted into the lumen of the gastrointestinal tract that is not absorbed. From these results, it would seem that an opportunity may exist to reduce FN excretion by reducing DMI while feeding a concentration of dietary energy, N, and other nutrients that are commensurate with the needs of the animal. The excretion of UN is most greatly affected by NI, increasing within the range of NI that entered the analysis up to a value approximately paralleling truly digested NI. As such, the majority of emphasis for reducing $\mathrm{N}$ excretions, particularly UN, should be placed on reducing NI.

Milk-fed calves averaged greater NR and marginal efficiency than weaned heifers, but there was limited evidence to suggest that the change in marginal efficiency was related to differences between diets as much as to changes associated with BW. Milk-fed calves had a substantially greater GNE than weaned heifers; however, differences in GNE between milk-fed and weaned cattle could be accounted for to a large degree by changes in basal $\mathrm{N}$ excretion. The $\mathrm{CP}$ concentration that maximized GNE was $18.9 \%$ for milk-fed calves and $14.2 \%$ for weaned cattle; weight-specific NI ( $\mathrm{g} / \mathrm{kg}$ of $\mathrm{BW}^{0.75}$ ) and ratio of $\mathrm{CP}$ to $\mathrm{ME}(\mathrm{MJ}$ of $\mathrm{CP} / \mathrm{MJ}$ of $\mathrm{ME}$ ) were expressions of NI for which a single level of NI was found to maximize GNE for both dietary populations. The NI that maximized the GNE of both milkfed and weaned calves was $1.84 \mathrm{~g} / \mathrm{kg}$ of $\mathrm{BW}^{0.75}$ and $22.5 \% \mathrm{MJ}$ of $\mathrm{CP} / \mathrm{MJ}$ of ME. From the results of this analysis, it can be concluded that responses in FN and UN to altered levels of NI are largely similar for milkfed and weaned dairy cattle; however, the NR or efficiency differences appeared to be less related to differences between diets than to changes associated with $\mathrm{BW}$ and basal $\mathrm{N}$ excretions.

\section{ACKNOWLEDGMENTS}

The authors would like to gratefully acknowledge $\mathrm{H}$. R. Conrad and G. A. Varga for their reviews and helpful discussions regarding the equations and results of this manuscript. The authors also thank C. M. Jones for editorial support.

\section{REFERENCES}

Allen, S. A., and E. L. Miller. 1976. Determination of nitrogen requirement for microbial growth from the effect of urea supplementation of a low $\mathrm{N}$ diet on abomasal $\mathrm{N}$ flow and $\mathrm{N}$ recycling in wethers and lambs. Br. J. Nutr. 36:353-368.

Bagg, J. G., D. G. Grieve, J. H. Burton, and J. B. Stone. 1985. Effect of protein on growth of Holstein heifer calves from 2 to 10 months. J. Dairy Sci. 68:2929-2939.

Baker, D. H. 1986. Problems and pitfalls in animal experiments designed to establish dietary requirements for essential nutrients. J. Nutr. 116:2339-2349.

Balch, C. C. 1967. Problems in predicting the value of non-protein nitrogen as a substitute for protein in rations for farm animal ruminants. World Rev. Anim. Prod. 3:84-91.

Bartlett, K. S., F. K. McKeith, M. J. VandeHaar, G. E. Dahl, and J. K. Drackley. 2006. Growth and body composition of dairy calves fed milk replacers containing different amounts of protein at two feeding rates. J. Anim. Sci. 84:1454-1467.

Bines, J. A., and C. C. Balch. 1973. Relative retentions in the nitrogen of urea and groundnut in isoenergenetic diets for growing heifers. Br. J. Nutr. 29:457-466.

Black, J. L., and D. A. Griffiths. 1975. Effects of live weight and energy intake on nitrogen balance and total $\mathrm{N}$ requirement of lambs. Br. J. Nutr. 33:399-413.

Blaxter, K. L., J. L. Clapperton, and F. W. Wainman. 1966. Utilization of energy and protein of same diet by cattle of different ages. J. Agric. Sci. 67:67-75.

Blaxter, K. L., and H. H. Mitchell. 1948. The factorization of the protein requirements of ruminants and of the protein values of feeds, with particular reference to the significance of the metabolic fecal nitrogen. J. Anim. Sci. 7:351-372.

Blaxter, K. L., and W. A. Wood. 1951a. The nutrition of the young Ayrshire calf. 1. The endogenous nitrogen and basal energy metabolism of the calf. Br. J. Nutr. 5:11-25.

Blaxter, K. L., and W. A. Wood. 1951b. The nutrition of the young Ayrshire calf. 4. Some factors affecting the biological value of protein determined by nitrogen-balance methods. Br. J. Nutr. 5:55-67.

Blome, R. M., J. K. Drackley, F. K. McKeith, M. F. Hutjens, and G. C. Mc Coy. 2003. Growth, nutrient utilization, and body composition of dairy calves fed milk replacers containing different amounts of protein. J. Anim. Sci. 81:1641-1655.

Bowers, H. B., T. R. Preston, I. Mc Donald, N. A. Mac Leod, and E. B. Philip. 1965. Intensive beef production. 4. Effect on nitrogen 
retention of all-concentrate diets containing different levels of fish meal. Anim. Prod. 7:19-25.

Brisson, G. J., H. M. Cunningham, and S. R. Haskell. 1957. The protein and energy requirements of young dairy calves. Can. J. Anim. Sci. 37:157-167.

Brody, S. 1945. Bioenergetics and Growth. Reinhold, New York, NY.

Broster, W. H., V. J. Tuck, and C. C. Balch. 1963. Experiments on nutrition of dairy heifer. 4. Protein requirements of 2-year-old heifers. J. Agric. Sci. 60:393-398.

Campbell, R. G., M. R. Taverner, and D. M. Curic. 1984. Effect of feeding level and dietary protein content on the growth, body composition and rate of protein deposition in pigs growing from 45 to $90 \mathrm{~kg}$. Anim. Prod. 38:233-240.

Campbell, R. G., M. R. Taverner, and D. M. Curic. 1985. The influence of feeding level on the protein requirement of pigs between 20 and $45 \mathrm{~kg}$ live weight. Anim. Prod. 40:489-496.

Carr, J. R., K. N. Boorman, and D. J. A. Cole. 1977. Nitrogen retention in pig. Br. J. Nutr. 37:143-155.

Cunningham, H. M., and G. J. Brisson. 1957. The endogenous urinary and metabolic fecal nitrogen excretions of newborn dairy calves. Can. J. Anim. Sci. 37:152-156.

Davis, C. L., and J. K. Drackley. 1998. The Development, Nutrition, and Management of the Young Calf. Iowa State Univ. Press, Ames.

de Lange, C. F. M., W. C. Sauer, and W. Souffrant. 1989. The effect of protein status of the pig on the recovery and amino acid composition of endogenous protein in digesta collected from the distal ileum. J. Anim. Sci. 67:755-762.

Donnelly, P. E., and J. B. Hutton. 1976. Effects of dietary protein and energy on growth of Friesian bull calves. 1. Food intake, growth, and protein requirements. N. Z. J. Agric. Res. 19:289-297.

Filliben, J. J. 1975. Probability plot correlation coefficient test for normality. Technometrics 17:111-117.

Fortin, A., S. Simpfendorfer, J. T. Reid, H. J. Ayala, R. Anrique, and A. F. Kertz. 1980. Effect of level of energy intake and influence of breed and sex on the chemical composition of cattle. J. Anim. Sci. 51:604-614.

Freetly, H. C., J. A. Nienaber, and T. M. Brown-Brandl. 2003. Relationship between aging and nutritionally controlled growth rate on heat production of heifers. J. Anim. Sci. 81:1847-1852.

Gabler, M. T., and A. J. Heinrichs. 2003. Effects of increasing dietary protein on nutrient utilization in heifers. J. Dairy Sci. 86:2170-2177.

Gabler, M. T., P. R. Tozer, and A. J. Heinrichs. 2000. Development of a cost analysis spreadsheet for calculating the costs to raise a replacement dairy heifer. J. Dairy Sci. 83:1104-1109.

Gerrits, W. J. J., G. H. Tolman, J. W. Schrama, S. Tamminga, M. W. Bosch, and M. W. A. Verstegen. 1996. Effect of protein and protein-free energy intake on protein and fat deposition rates in preruminant calves of 80 to $240 \mathrm{~kg}$ live weight. J. Anim. Sci. 74:2129-2139.

Graham, N. M., and T. W. Searle. 1972. Balances of energy and matter in growing sheep at several ages, body weights, and planes of nutrition. Aust. J. Agric. Res. 23:97-108.

Griffiths, T. W., and J. Connolly. 1977. Use of statistical relationships from balance trials to estimate nutrient requirements of growing cattle. Ir. J. Agric. Res. 16:11-20.

Gujarati, D. 1970. Use of dummy variables in testing for equality between sets of coefficients in linear regressions: A generalization. Am. Stat. 24:18-22.

Hayashi, H., M. Kawai, I. Nonaka, F. Terada, K. Katoh, and Y. Obara. 2006. Developmental changes in the kinetics of glucose and urea in Holstein calves. J. Dairy Sci. 89:1654-1661.

Heinrichs, A. J., and G. L. Hargrove. 1994. Standards of weight and height for Ayrshire, Brown Swiss, and Milking Shorthorn heifers. J. Dairy Sci. 77:1676-1681.

Heinrichs, A. J., and W. C. Losinger. 1998. Growth of Holstein dairy heifers in the United States. J. Anim. Sci. 76:1254-1260.

Hodgkinson, S. M., P. J. Moughan, G. W. Reynolds, and K. A. C. James. 2000. The effect of dietary peptide concentration on endogenous ileal amino acid loss in the growing pig. Br. J. Nutr. 83:421-430.
Hoffman, P. C., N. M. Esser, L. M. Bauman, S. L. Denzine, M. Engstrom, and H. Chester-Jones. 2001. Short communication: Effect of dietary protein on growth and nitrogen balance of Holstein heifers. J. Dairy Sci. 84:843-847.

Holter, J. A., and J. T. Reid. 1959. Relationship between the concentrations of crude protein and apparently digestible protein in forages. J. Anim. Sci. 18:1339-1349.

Hovell, F. D. D., E. R. Orskov, D. J. Kyle, and N. A. Mac Leod. 1987. Undernutrition in sheep. Nitrogen repletion by $\mathrm{N}$-depleted sheep. Br. J. Nutr. 57:77-88.

Kehar, N. D., R. Mukherjee, and K. C. Sen. 1943. Studies on protein metabolism. 1. Investigations upon the endogenous nitrogen metabolism of cattle. Ind. J. Vet. Sci. 13:257-262.

Kleiber, M. 1932. Body size and metabolism. Hilgardia 6:315-353.

Kohn, R. A., Z. Dou, J. D. Ferguson, and R. C. Boston. 1997. A sensitivity analysis of nitrogen losses from dairy farms. J. Environ. Manage. 50:417-428.

Kononoff, P. J., S. K. Ivan, and T. J. Klopfenstein. 2007. Estimation of the proportion of feed protein digested in the small intestine of cattle consuming wet corn gluten feed. J. Dairy Sci. 90:2377-2385.

Kyriazakis, I., and G. C. Emmans. 1992. The effects of varying protein and energy intakes on the growth and body composition of pigs. 2 . The effects of varying both energy and protein intake. Br. J. Nutr. 68:615-625.

Lalles, J. P., L. Montagne, C. Plut, and R. Toullec. 2001. Influence of dietary protein concentration on the morphology and enzyme activities of the small intestine of the pre-ruminant calf. Anim. Sci. 73:571-578.

Lindberg, J. E., and K. G. Jacobsson. 1990. Nitrogen and purine metabolism at varying energy and protein supplies in sheep sustained on intragastric infusion. Br. J. Nutr. 64:359-370.

Lofgreen, G. P., and M. Kleiber. 1953. The metabolic fecal nitrogen excretion of the young calf and the true digestibility of casein. J. Nutr. 49:183-190.

Lofgreen, G. P., J. K. Loosli, and L. A. Maynard. 1951. Comparative study of conventional protein allowances and theoretical requirements of growing Holstein heifers. J. Anim. Sci. 10:171-183.

Mallows, C. L. 1973. Some comments on Cp. Technometrics 15:661-675.

Marini, J. C., J. D. Klein, J. M. Sands, and M. E. Van Amburgh. 2004. Effect of nitrogen intake on nitrogen recycling and urea transporter abundance in lambs. J. Anim. Sci. 82:1157-1164.

Marini, J. C., and M. E. Van Amburgh. 2003. Nitrogen metabolism and recycling in Holstein heifers. J. Anim. Sci. 81:545-552.

Mason, V. C. 1969. Some observations on distribution and origin of nitrogen in sheep faeces. J. Agric. Sci. 73:99-111.

Miller, D. S., and P. R. Payne. 1962. Weight maintenance and food intake. J. Nutr. 78:255-262.

Miller, D. S., and P. R. Payne. 1963. A theory of protein metabolism. J. Theoret. Biol. 5:398-411.

Mitchell, H. H. 1924. A method of determining the biological value of protein. J. Biol. Chem. 58:873-903.

Montagne, L., R. Toullec, and J. P. Lalles. 2000. Quantitative and qualitative changes in endogenous nitrogen components along the small intestine of the calf. J. Sci. Food Agric. 80:2123-2134.

Moran, J. B., and J. E. Vercoe. 1972. Some factors affecting apparent nitrogen digestibility of roughage diets fed to cattle. J. Agric. Sci. 78:173-177.

Mosenthin, R., W. C. Sauer, H. Henkel, F. Ahrens, and C. F. M. de Lange. 1992. Tracer studies of urea kinetics in growing pigs. 2. The effect of starch infusion at the distal ileum on urea recycling and bacterial nitrogen excretion. J. Anim. Sci. 70:3467-3472.

Moughan, P. J., L. H. Jacobson, and P. C. H. Morel. 2006. A genetic upper limit to whole-body protein deposition in a strain of growing pigs. J. Anim. Sci. 84:3301-3309.

Mugerwa, J. S., and H. R. Conrad. 1971. Relationship of dietary nonprotein nitrogen to urea kinetics in dairy cows. J. Nutr. 101:1331-1342.

NRC. 2001. Nutrient Requirements of Dairy Cattle. 7th ed. Natl. Acad. Sci., Washington, DC.

Orskov, E. R. 1992. Protein Nutrition in Ruminants. Academic Press, London, UK. 
Orskov, E. R., C. Fraser, V. C. Mason, and S. O. Mann. 1970. Influence of starch digestion in large intestine of sheep on caecal fermentation, caecal microflora and faecal nitrogen excretion. Br. J. Nutr. 24:671-682.

Orskov, E. R., and N. A. Mac Leod. 1982. The determination of the minimal nitrogen excretion in steers and dairy cows and its physiological and practical implications. Br. J. Nutr. 47:625-636.

Orskov, E. R., D. E. Meehan, N. A. Mac Leod, and D. J. Kyle. 1999. Effect of glucose supply on fasting nitrogen excretion and effect of level and type of volatile fatty acid infusion on response to protein infusion in cattle. Br. J. Nutr. 81:389-393.

Ortigues, I., T. Smith, M. Gill, S. B. Cammell, and N. W. Yarrow. 1990. The effect of fish meal supplementation of a straw-based diet on growth and calorimetric efficiency of growth in heifers. Br. J. Nutr. 64:639-651.

Ouellet, D. R., M. Demers, G. Zuur, G. E. Lobley, J. R. Seoane, J. V. Nolan, and H. Lapierre. 2002. Effect of dietary fiber on endogenous nitrogen flows in lactating dairy cows. J. Dairy Sci. 85:3013-3025.

Rand, W. M., P. L. Pellett, and V. R. Young. 2003. Meta-analysis of nitrogen balance studies for estimating protein requirements in healthy adults. Am. J. Clin. Nutr. 77:109-127.

Raven, A. M. 1972. Nutritional effects of including different levels and sources of protein in milk replacers for calves. J. Sci. Food Agric. 23:517-526.

Robbins, K. R., H. W. Norton, and D. H. Baker. 1979. Estimation of nutrient requirements from growth data. J. Nutr. 109:1710-1714.

Roy, J. H. B. 1970. Protein in milk replacers for calves. J. Sci. Food Agric. 21:346-351.

Roy, J. H. B. 1980. The Calf. 4th ed. Butterworths, Boston, MA.

Roy, J. H. B., I. J. F. Stobo, H. J. Gaston, and J. Greatorex. 1970. Nutrition of veal calf. 2. Effect of different levels of protein and fat in milk substitute diets. Br. J. Nutr. 24:441-457.

Sandberg, F. B., G. C. Emmans, and I. Kyriazakis. 2005. Partitioning of limiting protein and energy in the growing pig: Testing quantitative rules against experimental data. Br. J. Nutr. 93:213-224.

SAS Institute. 2006. SAS User's Guide: Statistics. Version 9.1.3. SAS Inst. Inc., Cary, NC.

Schneider, B. H. 1934. The relationship of the metabolic nitrogen of the faeces to body weight and to food intake for rats. Biochem. J. 28:360-364.

Schroeder, G. F., E. C. Titgemeyer, M. S. Awawdeh, J. S. Smith, and D. P. Gnad. 2006a. Effects of energy level on methionine utilization by growing steers. J. Anim. Sci. 84:1497-1504.

Schroeder, G. F., E. C. Titgemeyer, M. S. Awawdeh, J. S. Smith, and D. P. Gnad. 2006b. Effects of energy source on methionine utilization by growing steers. J. Anim. Sci. 84:1505-1511.

Seal, C. J., and C. K. Reynolds. 1993. Nutritional implications of gastrointestinal and liver metabolism in ruminants. Nutr. Res. Rev. 6:185-208.

Smuts, D. B. 1935. The relation between the basal metabolism and the endogenous nitrogen metabolism, with particular reference to the estimation of the maintenance requirement of protein. J. Nutr. 9:403-433.
Stallcup, O. T., G. V. Davis, and L. Shields. 1975. Influence of dry matter and nitrogen intakes on fecal nitrogen losses in cattle. J. Dairy Sci. 58:1301-1307.

Stein, H. H., B. Seve, M. F. Fuller, P. J. Moughan, and C. F. M. de Lange. 2007. Invited review: Amino acid bioavailability and digestibility in pig feed ingredients: Terminology and application. J. Anim. Sci. 85:172-180.

Stobo, I. J. F., and J. H. B. Roy. 1973. Protein requirement of ruminant calf. 4. Nitrogen balance studies on rapidly growing calves given diets of different protein content. Br. J. Nutr. 30:113-125.

Storm, E., E. R. Orskov, and R. Smart. 1983. The nutritive value of rumen micro-organisms in ruminants. 2. The apparent digestibility and net utilization of microbial $\mathrm{N}$ for growing lambs. Br. J. Nutr. 50:471-478.

St-Pierre, N. R. 2001. Invited review: Integrating quantitative findings from multiple studies using mixed model methodology. J. Dairy Sci. 84:741-755.

Suits, D. B. 1957. Use of dummy variables in regression equations. J. Am. Stat. Assoc. 52:548-551.

Sunny, N. E., S. L. Owens, R. L. Baldwin, S. W. El-Kadi, R. A. Kohn, and B. J. Bequette. 2007. Salvage of blood urea nitrogen in sheep is highly dependent on plasma urea concentration and the efficiency of capture within the digestive tract. J. Anim. Sci. 85:1006-1013.

Suryawan, A., J. Escobar, J. W. Frank, H. V. Nguyen, and T. A. Davis. 2006. Developmental regulation of the activation of signaling components leading to translation initiation in skeletal muscle of neonatal pigs. Am. J. Physiol. Endocrinol. Metab. 291:E849E859.

Swanson, E. W. 1977. Factors for computing requirements of protein for maintenance of cattle. J. Dairy Sci. 60:1583-1593.

Swanson, K. C., J. A. Benson, J. C. Matthews, and D. L. Harmon. 2004. Pancreatic exocrine secretion and plasma concentration of some gastrointestinal hormones in response to abomasal infusion of starch hydrolyzate and/or casein. J. Anim. Sci. 82:1781-1787.

Van Soest, P. J. 1967. Development of a comprehensive system of feed analyses and its application to forages. J. Anim. Sci. 26:119-128.

Van Soest, P. J., and V. C. Mason. 1991. The influence of the Maillard reaction upon the nutritive value of fibrous feeds. Anim. Feed Sci. Technol. 32:45-53.

Veira, D. M., G. K. Macleod, J. H. Burton, and J. B. Stone. 1980 Nutrition of the weaned Holstein calf. 2. Effect of dietary protein level on nitrogen balance, digestibility and feed intake. J. Anim. Sci. 50:945-951.

Walker, D. M., and B. W. Norton. 1971. Nitrogen balance studies with milk-fed lamb. 9. Energy and protein requirements for maintenance, live-weight gain and wool growth. Br. J. Nutr. 26:15-29.

Whitelaw, F. G., T. R. Preston, and R. D. Ndumbe. 1961. The nutrition of the early-weaned calf. 1 . The effect on nitrogen retention of diets containing different levels of groundnut meal. Anim. Prod. $3: 121-126$

Wray-Cahen, D., H. V. Nguyen, D. G. Burrin, P. R. Beckett, M. L. Fiorotto, P. J. Reeds, T. J. Wester, and T. A. Davis. 1998. Response of skeletal muscle protein synthesis to insulin in suckling pigs decreases with development. Am. J. Physiol. Endocrinol. Metab. 38:E602-E609. 